\title{
Physiological and metabolic responses to prolonged hypoxia and extreme cold: Preliminary data from the White Mars Antarctica winter expedition
}

\author{
Katie A O'Brien ${ }^{1 *}$, Ross Pollock ${ }^{1}$, Mike Stroud ${ }^{2}$, Alex Kumar ${ }^{3}$, Robert J Lambert ${ }^{4}$, David A Green ${ }^{1}$, \\ Lindsay M Edwards', Stephen Harridge ${ }^{1}$
}

From 15th International Conference on Environmental Ergonomics (ICEE XV)

Portsmouth, UK. 28 June - 3 July 2015

\section{Introduction}

The Antarctic winter is amongst the most extreme environments on earth. Human adaptation to this environment, where severe cold is coupled with moderate altitudes, is poorly understood. In this study, a number of physiological and metabolic measurements were made on a small group of trekkers before and after an attempted winter crossing of Antarctica (White Mars Expedition).

\section{Methods}

5 male subjects aged 28-54 yrs were assessed prior to and following a 24 week stay in Antarctica, including 14 weeks above $2,500 \mathrm{~m}$. Measurements included assessment of body fat and bone mineral density (DXA), cardiorespiratory responses to an incremental exercise test, lung and cardiovascular function as well as metabolomic analysis of serum using ${ }^{1} \mathrm{H}-\mathrm{NMR}$ spectroscopy.

\section{Results}

Significant changes were found in the following parameters pre to post expedition, identified using a paired Student t test (mean (SD), $\mathrm{p}<0.05)$. There was an increase in \% lean tissue $(79+4$ vs. $81+3 \%)$, a decrease in \% fat tissue (21(4) vs. 19(3) \%) and body fat mass (16(5) vs. 14(4) kg), although whole body weight did not change. Both spine bone mineral density $(1.2(0.05)$ vs. 1.13(0.04) g.cm ${ }^{2}$ ) and $\mathrm{FEV}_{1}: \mathrm{FVC}(68(10)$ vs. $62(8))$

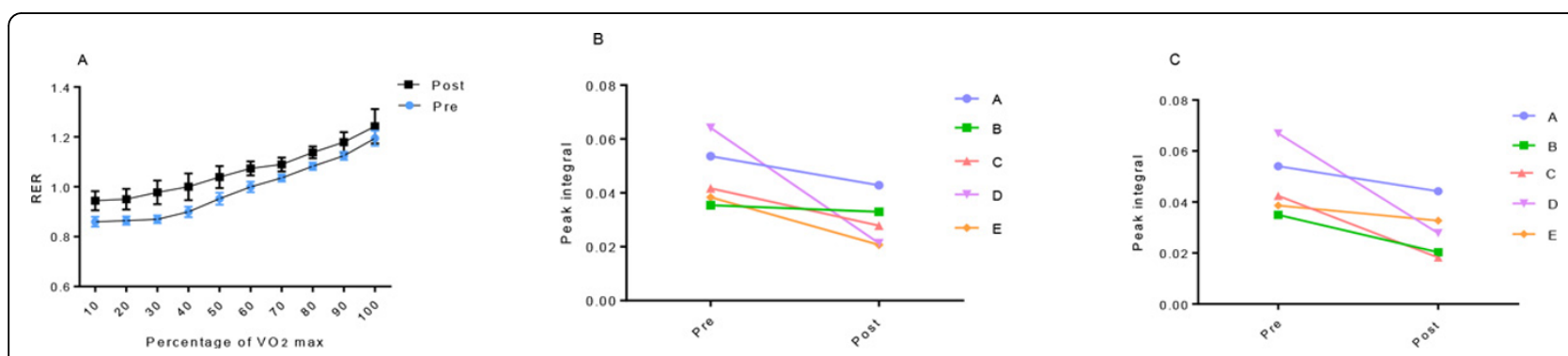

Figure $1 \mathrm{~A}$, Mean (SD) RER recorded for each percentile of $\mathrm{VO}_{2 \max }$ test, changes in the peak integrals of glucose (B) and the fatty acid $\mathrm{CH}_{2}$ resonance $(C)$ pre and post expedition.

\footnotetext{
* Correspondence: katie.obrien@kcl.ac.uk

'Centre of Human and Aerospace Physiological Sciences, King's College

London, London, UK

Full list of author information is available at the end of the article
} 
were decreased. $\mathrm{VO}_{2 \max }$ did not significantly change from the pre-expedition $42 \mathrm{~mL} . \mathrm{kg}$.min, however an increase was observed pre to post expedition in the respiratory exchange ratio (RER) at each stage (10\%) of the $\mathrm{VO}_{2 \max }$ test (Figure 1A). Metabolomics analysis of serum samples revealed changes in two peaks within principal component 2: glucose and a fatty acid $\mathrm{CH}_{2}$ resonance (Figure $1 \mathrm{~B}$ and $1 \mathrm{C}$ ).

\section{Discussion}

These results are suggestive of a number of physiological changes resulting from prolonged exposure to the Antarctic winter. In particular, we observed a change in metabolic signature involving changes to both glucose and fatty acid homeostasis with a shift towards increased reliance on carbohydrate metabolism during exercise.

\section{Conclusion}

This study has highlighted areas of interest for future investigations into the physiological responses to this unique environment.

\section{Authors' details}

${ }^{1}$ Centre of Human and Aerospace Physiological Sciences, King's College London, London, UK. ${ }^{2} \mathrm{NIHR}$ Biomedical Research Centre for Nutrition, Southampton, UK. ${ }^{3}$ University Hospitals of Leicester, UK \& University of Fribourg, Switzerland. ${ }^{4}$ Dept. of Trauma and Orthopaedic Surgery, Royal Infirmary of Edinburgh, UK.

Published: 14 September 2015

doi:10.1186/2046-7648-4-S1-A121

Cite this article as: $\mathrm{O}^{\prime}$ Brien et al:: Physiological and metabolic responses to prolonged hypoxia and extreme cold: Preliminary data from the White Mars Antarctica winter expedition. Extreme Physiology \& Medicine 2015 4(Suppl 1):A121.
Submit your next manuscript to BioMed Central and take full advantage of:

- Convenient online submission

- Thorough peer review

- No space constraints or color figure charges

- Immediate publication on acceptance

- Inclusion in PubMed, CAS, Scopus and Google Scholar

- Research which is freely available for redistribution

Submit your manuscript at www.biomedcentral.com/submit 